\title{
Evaluation of Some Heavy Metals Bio-Accumulation in Meat and Haemolymph of African Landsnail (Archachatina Marginata Swainson)
}

\section{${ }^{1}$ ADEBISI -FAGBOHUNGBE, TA; ${ }^{1}$ KEHINDE, AS; ${ }^{2}$ BABATUNDE, OO; 1 ODIAKA, IE; ${ }^{1}$ ABULDULAZEEZ, FA; ${ }^{1}$ GANIYU, OA; ${ }^{3}$ OYEDIRAN, B; ${ }^{1}$ UDAGHE, MO}

\author{
*I Department of Wildlife and Ecotourism, Forestry Research Institute of Nigeria. \\ ${ }^{2}$ Department of Wood and Paper Technology, Federal College of Forestry, Jericho, Ibadan, Oyo State, Nigeria \\ ${ }^{3}$ Federal College of Wildlife Management, New Bussa, Nigeria \\ *Corresponding Author: Sollybee2012@gmail.com
}

\begin{abstract}
The impact of captive rearing of snails (Archachatina marginata) on the bio-accumulation of some heavy metals (HMs) ( $\mathrm{Fe}, \mathrm{Mn}, \mathrm{Cu}, \mathrm{Pb}, \mathrm{Co}, \mathrm{Ni}, \mathrm{Cd}$ and $\mathrm{Cr}$ ) in the meat and haemolymph was evaluated in a two treatment trial (snails from the wild, (SW) and captive reared snails, (SC), each comprised of sixty snails of three replicates. All data collected (using standard analytical procedures) were subjected to ANOVA and significant means separated by Duncan Multiple Range Test. The trial revealed that the meat of SC had outstanding $(\mathrm{P}>0.05) \mathrm{Fe}(22.30 \mathrm{mg} / \mathrm{kg})$ and $\mathrm{Mn}$ $(4.79 \mathrm{mg} / \mathrm{kg})$, with no significant variation for $\mathrm{DM}$, while the haemolymph recorded non-significant $(\mathrm{P}<0.05)$ concentration for $(\mathrm{Mn}, \mathrm{Pb}, \mathrm{Co}, \mathrm{Ni}, \mathrm{Cd}$ and $\mathrm{Cr})$. Its levels of $\mathrm{Fe}(3.50 \mathrm{mg} / \mathrm{kg})$ and $\mathrm{Cu}(2.06 \mathrm{mg} / \mathrm{kg})$ were however significantly $(\mathrm{P}>0.05)$ impacted by captive rearing. Generally the level of $\mathrm{Cr}$ in the meat and haemolymph were higher than $0.05 \mathrm{mg} / \mathrm{kg}$ recommendation by WHO, hence snail meat and haemolymph must be consumed with caution and guidance
\end{abstract}

\section{DOI:https://dx.doi.org/10.4314/jasem.v25i9.29}

Copyright: Copyright $\odot 2021$ Adebisi-Fagbohungbe et al. This is an open access article distributed under the Creative Commons Attribution License (CCL), which permits unrestricted use, distribution, and reproduction in any medium, provided the original work is properly cited.

Dates: Received: 09 May 2021; Revised: 12 August 2021; Accepted: 12 September 2021

Keywords: Snail meat, haemolymph, bio-accumulation, heavy metals, captivity, wild

Heavy metals have become a public health problem worldwide, due to their potential toxic effect and ability to bio-accumulate in the ecosystem (Kehinde and Adelakun, 2019). All gastropods and aquatic life are in contact with soil and water, which makes them prone to pollution from human agricultural practices, industrial and domestic wastes. The presence of heavy metals in food is deleterious to human health, if it is above the tolerable level recommended by the world health organization (ATSDR, 2019, Honggang et al., 2010). It is inappropriate, to completely discriminate against heavy metals, they play important roles in cellular metabolism, maintenance of cellular osmotic gradient and sustainability of body physiology and the ecosystem (Farombi et al., 2007). Heavy metal bioaccumulation is triggered through the food chain due to the absorption of these metals from water, sewage, agrochemicals, industrial wastes and wastes from mining centres (Alam et al., 2003, Agbon and Omoniyi, 2010). It is very common in the Southern parts of Nigeria to found gatherers collecting snails, immediately after rain (Kehinde et al., 2020). These animals feed on forages, organic matters and soil, which have all been implicated in the storage of heavy metals in order to determine the safety of snail meat consumption in the areas where they are found, all the common breeds (Archachatina marginata, Achatina achatina, Achatina falica and Limicolaria species) must be screened to determine if they are fit for human consumption. The focus of conservations has shifted to the farming of snails (ex-situ conservation); it is now a common practice among farmers to raise snails in captivity in order to guarantee all year round availability (Popoola, 2020) and address the challenges of extinction (Omole, 2002). This study tries to evaluate the meat and haemolymph of snails raised in captivity and those from the wild for heavy metals, which have been implicated as health risk to the consumers of such products, consequently compromising the benefits of snail meat and haemolymph consumption; for the supply of protein, iron, potassium, calcium and phosphorus, coupled with the tender nature of the meat and its low level of cholesterol. This study determine the bioaccumulation of heavy metals, such as $\mathrm{Fe}, \mathrm{Mn}, \mathrm{Ca}, \mathrm{Pb}$, $\mathrm{Co}, \mathrm{Ni}, \mathrm{Cd}, \mathrm{Cr}$, in the meat and haemolymphs of snail collected from the wild and those reared in captivity; which will guide on the safety of consumption of snail and its products in the study area. 


\section{MATERIALS AND METHODS}

Sources of Experimental Snails (Archachatina marginata: There are two sources of snails adopted for this trial, the first source is from the wild (SW), and the second source is from captive reared snails (SC) from Teaching and Research farm of Forestry Research Institute of Nigeria and from selected snail farmers. Sixty snails each were procured from the two sources and replicated thrice at twenty snails per replicate. The snails from the wild were sourced from gatherers at Mamu market at Oluyole Local Government Area of Oyo State.

Stabilization and detoxification of the snails: The snails were brought to stabilization wooden cages for five days and fed conventional ration, with $30 \%$ crude protein and $2400 \mathrm{kcal} / \mathrm{kg}$ M.E. the snails in each replicate were housed together and offered feed and water ad libitum. This was to detoxify the animals for purity of samples of meat and haemolymph.

Experimental treatments: There were two treatments, which represented snail from the wild (SW) and captive reared snails (SC). Sixty snails per treatment were adopted, while each was replicated thrice, at 20snails per replicate.

Meat and haemolymph collection: The snails were cleaned to avoid sample contamination, their shells were carefully opened at the pointed end and the bluish portion of haemolymph was collected and pooled together for eventual collected of $5 \mathrm{ml}$ per replicate. Meat samples were collected by the methods of Omole (2002).

Chemical Analyses of Snail and Haemolymph: The collected samples of meat and haemolymph from the two treatments and their replicates were heat treated in a muffle furnace at $45^{\circ} \mathrm{C}$ to remove any suspected aroma and their powder digested according to Prabhat et al., (2019). The samples were digested to determine the concentration of the heavy metals, using Atomic Absorption Spectrophotometry (AAS), Perkin-Elmer Spectrophotometer (AAnalyst 200 model).

Experimental Design and Statistical Analysis: The experiment was designed with two treatments and three replicates, in a one-way Analysis of Variance. All data collected were analysed by the principles of ANOVA, while significant means were separated using Duncan Multiple Range Test (1955).

\section{RESULTS AND DISCUSSION}

Table 1 shows the levels of evaluated heavy metals in the meat of snails sourced from the wild and those that were captive reared. The concentrations of heavy metals determined were for $\mathrm{Fe}, \mathrm{Mn}, \mathrm{Cu}, \mathrm{Pb}, \mathrm{Co}, \mathrm{Ni}$, $\mathrm{Cd}$, and $\mathrm{Cr}$, the concentration of the metals in the meat compared $(\mathrm{P}<0.05)$, except for $\mathrm{Fe}$ and $\mathrm{Mn}$, which were significantly $(\mathrm{P}>0.05)$ higher in captive reared snails. The levels of Fe and Mn obtained in this trial were higher than what was reported by Akinnusi et al., (2019), consequently promoting the health benefits derivable from the two mineral salts. It has also corroborated the findings of Omole (2002) that snail meat is a good source of cheap nutritional iron for the rural dwellers, he further submitted that the iron level of snail meat is higher than what is found in the meat of broiler $(1.25 \mathrm{mg} / 100 \mathrm{~g})$, goat $(0.80 \mathrm{mg} / 100 \mathrm{~g})$ and tilapia fish $(0.55 \mathrm{mg} / 100 \mathrm{~g})$. The levels of chromium in the two treatments SW $(1.80 \mathrm{ug} / \mathrm{dl})$ and SC $(2.00 \mathrm{ug} / \mathrm{dl})$ for the meat were above the FAO and WHO (2016) reference value of $0.05 \mathrm{ug} / \mathrm{g}$ for food crops and vegetables reported by Prabhat et al., 2019; the meat of snail for the fear of chromium level must be consumed with caution, because they may not be degraded by heat treatment during cooking. It has equally been submitted by different authors that dosage of heavy metal intake is calculated based on quantity of food consumed multiplied by concentration, this should guide in the determination of heavy metal intake in any food consumed. It is important to note that the concentration of heavy metals in snail varies with location, due to differences in snail type, concentration of heavy metals and level of environmental pollution, (Ademolu et al., 2011). Table 2 elicited the levels of some heavy metals (Fe, $\mathrm{Mn}, \mathrm{Cu}, \mathrm{Pb}, \mathrm{Co}, \mathrm{Ni}, \mathrm{Cd}$ and $\mathrm{Cr}$ ) in the haemolymph of Archachatina marginata from the wild and captive reared. The trial has revealed the non-presence of $\mathrm{Pb}$ and $\mathrm{Cd}$ in the haemolymph from the two sources, supporting the assertion that snails are good utilizers of some mineral salts, due to their possession of mechanism for the excretion of these metals. It was obvious that the levels of $\mathrm{Fe}$ and $\mathrm{Cu}$ were significantly elevated in $\mathrm{SC}$, an indication that more $\mathrm{Fe}$ and $\mathrm{Cu}$ was found in the haemolymph of captive reared snails and may improve oxidative phosphorylation and cellular energy production in addition, the Copper impacts the blue colour of the haemolymph and has been reported to play important role in blood pressure suppression. Table 1 shows the levels of evaluated heavy metals in the meat of snails sourced from the wild and those that were captive reared. The concentrations of heavy metals determined were for $\mathrm{Fe}, \mathrm{Mn}, \mathrm{Cu}, \mathrm{Pb}, \mathrm{Co}, \mathrm{Ni}$, $\mathrm{Cd}$, and $\mathrm{Cr}$, the concentration of the metals in the meat compared $(\mathrm{P}<0.05)$, except for $\mathrm{Fe}$ and $\mathrm{Mn}$, which were significantly $(\mathrm{P}>0.05)$ higher in captive reared snails. Th[e levels of Fe and Mn obtained in this trial were higher than what was reported by Akinnusi et al., 
(2019), consequently promoting the health benefits derivable from the two mineral salts. It has also corroborated the findings of Omole (2002) that snail meat is a good source of cheap nutritional iron for the rural dwellers, he further submitted that the iron level of snail meat is higher than what is found in the meat of broiler $(1.25 \mathrm{mg} / 100 \mathrm{~g})$, goat $(0.80 \mathrm{mg} / 100 \mathrm{~g})$ and tilapia fish $(0.55 \mathrm{mg} / 100 \mathrm{~g})$. The levels of chromium in the two treatments SW $(1.80 \mathrm{ug} / \mathrm{dl})$ and SC $(2.00 \mathrm{ug} / \mathrm{dl})$ for the meat were above the FAO and WHO (2016) reference value of $0.05 \mathrm{ug} / \mathrm{g}$ for food crops and vegetables reported by Prabhat et al., 2019; the meat of snail for the fear of chromium level must be consumed with caution, because they may not be degraded by heat treatment during cooking. It has equally been submitted by different authors that dosage of heavy metal intake is calculated based on quantity of food consumed multiplied by concentration, this should guide in the determination of heavy metal intake in any food consumed. It is important to note that the concentration of heavy metals in snail varies with location, due to differences in snail type, concentration of heavy metals and level of environmental pollution, (Ademolu et al., 2011). Table 2 elicited the levels of some heavy metals (Fe, $\mathrm{Mn}, \mathrm{Cu}, \mathrm{Pb}, \mathrm{Co}, \mathrm{Ni}, \mathrm{Cd}$ and $\mathrm{Cr}$ ) in the haemolymph of Archachatina marginata from the wild and captive reared.

Table 1: Concentration of Some Heavy Metals in the Meat of

\begin{tabular}{|c|c|c|c|}
\hline $\begin{array}{l}\text { Treatment } \\
\text { Parameters }(\mathrm{mg} / \mathrm{kg})\end{array}$ & SW & $\mathrm{SC}$ & SEM? \pm \\
\hline $\mathrm{Fe}$ & $18.10^{\mathrm{b}}$ & $22.30^{\mathrm{a}}$ & 1.50 \\
\hline $\mathrm{Mn}$ & $3.39^{\mathrm{b}}$ & $4.79^{\mathrm{a}}$ & 1.00 \\
\hline $\mathrm{Cu}$ & 9.00 & 10.00 & 1.2 \\
\hline $\mathrm{Pb}$ & 0.01 & 0.01 & 0.02 \\
\hline $\mathrm{Co}$ & 0.02 & 0.03 & 0.01 \\
\hline $\mathrm{Ni}$ & 3.00 & 3.00 & 0.05 \\
\hline $\mathrm{Cd}$ & $5 \times 10^{-4}$ & $3 \times 10^{-4}$ & 0.03 \\
\hline $\mathrm{Cr}$ & 1.80 & 2.00 & 0.05 \\
\hline
\end{tabular}

$a b: \overline{\text { Means along the same column with different superscripts }}$ are significantly $(P>0.05)$ different; $S W$ - Snail sourced from the wild; $S C$ - Captive reared snail

Table 2; Concentration of Some Heavy Metals in the Haemolymph of Snail from the Wild and Captive Reared Snail

\begin{tabular}{llll}
\hline Treatment & $\mathrm{SW}$ & $\mathrm{SC}$ & $\mathrm{SEM} \pm$ \\
Parameters $(\mathrm{mg} / \mathrm{kg})$ & & & \\
\hline $\mathrm{Fe}$ & $18.10^{\mathrm{b}}$ & $22.30^{\mathrm{a}}$ & 1.50 \\
$\mathrm{Mn}$ & $3.39^{\mathrm{b}}$ & $4.79^{\mathrm{a}}$ & 1.00 \\
$\mathrm{Cu}$ & 9.00 & 10.00 & 1.20 \\
$\mathrm{~Pb}$ & 0.01 & 0.01 & 0.02 \\
$\mathrm{Co}$ & 0.02 & 0.03 & 0.01 \\
$\mathrm{Ni}$ & 3.00 & 3.00 & 0.05 \\
$\mathrm{Cd}$ & $5 \times 10^{-4}$ & $3 \times 10^{-4}$ & 0.03 \\
$\mathrm{Cr}$ & 1.80 & 2.00 & 0.05 \\
\hline a, $b$ : Means with different superscripts along the same row are \\
\multicolumn{4}{r}{ significantly $(P>0.05)$ different from each other }
\end{tabular}

The trial has revealed the non-presence of $\mathrm{Pb}$ and $\mathrm{Cd}$ in the haemolymph from the two sources, supporting the assertion that snails are good utilizers of some mineral salts, due to their possession of mechanism for the excretion of these metals. It was obvious that the levels of $\mathrm{Fe}$ and $\mathrm{Cu}$ were significantly elevated in $\mathrm{SC}$, an indication that more $\mathrm{Fe}$ and $\mathrm{Cu}$ was found in the haemolymph of captive reared snails and may improve oxidative phosphorylation and cellular energy production in addition, the Copper impacts the blue color of the haemolymph and has been reported to play important role in blood pressure suppression.

The levels of other heavy metals in the haemolymph comparable $(\mathrm{P}<0.05)$ (Adeemolu et al., 2011, Sam et al., 2019 and Sodipe et al., 2019). It should be noted that the levels of $\mathrm{Cr}$ in snail meat and haemolymph were higher than the recommended guidelines of $0.05 \mathrm{mg} / \mathrm{kg}$ by FAO and WHO, hence the consumption of snail products must be regulated, considering the level of $\mathrm{Cr}$, especially for the haemolymph that is taken without any treatment.

Conclusion: In conclusion, the trial has shown that treatments had no effect $(\mathrm{P}<0.05)$ on the level of $\mathrm{Cu}$, $\mathrm{Pb}, \mathrm{Co}, \mathrm{Ni}, \mathrm{Cd}$, and $\mathrm{Cr}$ in the meat of snail; however $\mathrm{Fe}$ and $\mathrm{Mn}$ were significantly $(\mathrm{P}>0.05)$ improved. The levels of $\mathrm{Fe}$ and $\mathrm{Cu}$ in the haemolymph were more outstanding $(\mathrm{P}>0.05)$ in SC. It is recommended that snail meat should be consumed with caution considering the possibility of bio-accumulating some heavy metals from the environment.

\section{REFERENCES}

Ademolu, KO, Jayeola, OA, Dedeke, GA and Idowu, $A B$ (2011): Comparative analyses of the growth performance and haemolymph biochemical properties of normal and albino giant land snail (Archachatina marginata) Ethiopian J. of Environ. Studies and Mgt. ((EJESM) 4: 101 - 106

Agbon, AO and Omoniyi, IT (2010): Heavy metals in some fish species of Oyan Lake, South West Nigeria, Nig. J. of Fisheries, 7: (1-2): 91-99

Akinnusi, O, Oni, OO and Ademolu, KO (2019): variation in chemical composition of shell and haemolymph of Giant Land Snail (Archachatina marginata) during wet and dry seasons in Nig.J. of Molluscan Res. 5: 31 - 36

Alam, .MGM, Snow, T and Tanaka, A (2003): Arsenic and heavy metal contamination of vegetables grown in Samta Village, Bamgladesh Sc. Total Environ. 308(1-3): 83-96 
ATSDR (2007): Toxicological profile for Barium US Department of Health and Human Services, Public Health Services Atlanta, GA.

Duncan, DB. (1955): Multiple Range and Multiple F Test Biometrics 11: $1-42$.

Farombi, EO,Adelowo, OA and Ajimoko, YR (2007): Bio-markers of oxidative stress and heavy metals level as indicators of environmental pollution in African cat fish (Clarias gariepinus) from Oyan River. Int. J. of Env. Res. and Pub. Health. 4(2): $158-165$

Hongang, Z Baoshan, CRang, X and Hui, Z (2010): Heavy metals in water, soils and plants in Riparian wetlands in the Pearl River estuary. South China Procedia Env. Sci. 2: 1344 - 1354

Kehinde, AS and Adelakun, KM (2019): Occurrence of some heavy metals in selected fish species of river Oli, Kainji Lake National Park, Nigeria. SINET: Ethiopian J. of Sci., Vol 42(1): $18-24$

Kehinde, AS, Adelakun, KM, Halidu, TO, Babatunde, TO and Fadimu, BO (2020): Biochemical evaluation of meat and haemolymph of African Land Snail (Archachatina marginata, Swainson) in Southwest Nigeria. Egyptian Society of Ani. Prod. Vol 57(3).pp523-529

Lin, E, Enobakhare, V and Ilechie, I (2006): Bioaccumulation of heavy metals $(\mathrm{Cu}, \mathrm{Zn}, \mathrm{Fe})$ in fresh water snail (Pila ovate) from Ikpoba River of southwestern Nigeria. J. of Aquatic Sci. 21: 23 -28 .

Popoola, YA (2020): Performance and cost benefits of snails fed diet containing varying levels of African Yam Beam meal. J. of Molluscan Res. 6: $23-29$.

Prabhat, KR, Sang, SL Ming, Z, Yiu, FT and Kinhyun, K (2019): Heavy metals in food crops; health risks fate, mechanisms and management. Environ. Int. 125: 365 - 385.

Sam, IM, Essien, CA, Christopher, GI and Ebenso, IC (2019): Relationship among performance characteristics and confirmation traits in snails (Archachatina marginata) raised in the tropics. J. of Molluscan Res. 5: 37 - 42.

Sodipe, OG, Ajayi, OA, Abiola, MO and Osinowo, OA (2019): The effects of organo-phosphate in the growth performance of Archachatina marginata in southwestern Nigeria. J. of Molluscan Res. 5: 10 -14.

Agbon, AO and Omoniyi, IT (2010): Heavy metals in some fish species of Oyan Lake, Southwest Nigeria, Nig. J. of Fisheries 7: $(1-2)$ : $91-99$.

World Health Organization (WHO) (2008): Guidelines for drinking water quality $3^{\text {rd }}$ edition. Health criteria and supporting information. WHO Geneva pp. 668 